\title{
Pengembangan Potensi Lokal Pesisir Mengolah Ikan Menjadi Nugget Guna Meningkatkan Pendapatan Ekonomi Masyarakat Nelayan di Seuneubok Aceh
}

\author{
Al Fatah*1, Nova Purnama Lisa ${ }^{2}$ \\ 1,2Teknik Sipil, Universitas Samudra, Indonesia \\ *e-mail alfatah182000@gmail.com ${ }^{1}$,novapurnamalisa@unsam.ac.id ${ }^{2}$
}

\begin{abstract}
Abstrak
Desa Seuneubok Aceh memiliki sumber daya alam yang melimpah. Baik dalam bidang hasil laut dan di bidang pertanian. karena lokasinya sangat cukup strategis yaitu berada didekat pesisir pantai. Masyarakat Desa Seuneubok Aceh pada umumya setiap individual masyarakatnya hanya bergantung pada hasil tangkap laut dan pertanian saja. Sehingga pendapatan yang dimiliki masyarakat cenderung dikategorikan kurang atau belum maksimal. Padahal potensi sumber daya yang dimiliki di Desa Seuneubok Aceh sangat banyak. Masyarakat di Desa Seunebok Aceh hasil panen yang didapatkan baik dalam bidang pertanian maupun bidang perikanan dijual dengan cara produk mentahan terkhususnya dibidang perikanan. Padahal potensi seperti komoditas ikan yang melimpah bisa dikembangkan menjadi bermacam produk olahan makanan yang mempunyai nilai jual yang tinggi. misalnya makanan indutrsi olahan seperti nugget ikan tongkol. Nugget ikan tongkol merupakan makan olahan yang mudah untuk dikonsumsi dan memiliki tinggi protein. Kandungan protein yang dimiliki pada ikan tongkol yakni sebesar $25 \%$. Protein yang dimiliki sangat baik bagi tubuh manusia. Dikarenakan protein ikan bisa sebagai penggnti protein yang ada pada daging. Ikan tongkol juga salah satu komoditas ikan yang sangat mudah ditemukan pada Desa Seuneubok Aceh. komposisi gizi yang tergandung pada olahan makanan nugget ikan tongkol yaitu 15\% yakni meliputi kadar air, abu, protein, lemak, dan kabohidrat. Tujuan program ini dilakukan yaitu untuk membantu meningkatkan pendapatan ekonomi masyarakat Desa Seuneubok Aceh serta Mengembangkan pontensi laut yang dimiliki secara maksimal. Masyarakat Seuneubok Aceh diharapkan nantiknya tidak lagi berfokus pada hasil penen tangkap ikan maupun pertanian saja sebagai mata pencaharian. Melainkan bisa melalui program produk olahan nugget ikan tongkol yang dikembangkan. tahapan untuk melakukan pembuatan produk olahan makanan ikan nugget ikan yakni memobilisasi masyarakat, lalu mengedukasi masyarakat melalui penyuluhan dan praktik di salah satu rumah warga. Dari proses pengambilan isi daging segar ikan tongkol, penggorengan dan hingga pengemasan. Masyarakat tertarik dan senang dalam kegiatan yang dilakukan. Program ini menjadi suatu inovasi baru bagi masyarakat Seuneubok Aceh. Masyarakat setempat bisa menambah income melalui penjualan yang dihasikan. Sistem penjualan secara offline sasaran market tergantung pasar yang mengutungkan di daerah tersebut. Produk makanan nugget ini diharapkan memproduksi perharinya mencapai 20-50 pcs.
\end{abstract}

Kata kunci: Ikan Tongkol, Nelayan, Nugget Ikan, Pangan Lokal, Pesisir Seuneubok

\begin{abstract}
Seuneubok Aceh village has abundant natural resources. Both in the field of marine products and in agriculture. because the location is quite strategic which is near the coast. The people of Seuneubok Aceh Village in general, each individual community only depends on marine catches and agriculture. So that the income of the community tends to be categorized as less or not optimal. Even though the potential of resources in Seuneubok Village, Aceh is very much. Communities in Seunebok Aceh Village, the harvests obtained both in agriculture and in the field of fisheries are sold by means of raw products, especially in the field of fisheries. Whereas potential such as abundant fish commodities can be developed into various processed food products that have a high selling value. for example, processed industrial foods such as tuna nuggets. Tuna nuggets are processed foods that are easy to consume and high in protein. The protein content in tuna is $25 \%$. The protein that is owned is very good for the human body. Because fish protein can be used as a substitute for protein in meat. Tuna is also one of the fish commodities that are very easy to find in Seuneubok Village, Aceh. The nutritional composition contained in the processed food of tuna fish nuggets is $15 \%$ which includes water, ash, protein, fat, and carbohydrates content. The purpose of this program is to help increase the economic income of the Seuneubok Village community in Aceh and develop the potential of the sea to the maximum. It is hoped that the Seuneubok Aceh community will no longer focus on fishing or agriculture as a source of livelihood. But it could be through a program of processed tuna fish nuggets that was developed. The steps for making fish nugget processed food products are mobilizing the community, then
\end{abstract}


educating the community through counseling and practice in one of the residents' homes. From the process of taking the contents of the fresh meat of tuna, frying and packaging. The community is interested and happy in the activities carried out. This program is a new innovation for the people of Seuneubok Aceh. Local people can increase their income through the sales they generate. The sales system is managed both online and offline depending on the profitable market in the area. This nugget food product is expected to produce 20-50 pcs per day.

Keywords: Fish Nuggets, Fishermen, Local Food, Fishermen, Seuneubok Coast, Tuna Fish

\section{PENDAHULUAN}

Desa Seuneubok Aceh merupakan salah satu desa pesisir yang terletak di Kecamatan Peureulak, Kabupaten Aceh Timur yang terdiri dari 4 dusun yaitu Dusun Matang Mibong, Dusun Bangka Rimueng, Dusun Barat dan Dusun Timur dengan jumlah penduduk sebanyak 1500 jiwa.

mayoritas penduduk Desa Seuneubok Aceh berprofesi sebagai nelayan dan petani. Dimana dapat diketahui masyarakat memiliki lahan tambak dan lahan pertanian sendiri. Masyarakat setempat biasanya memanfaatkan hasil panen khususnya dari tangkapan ikan hanya sebagai kebutuhan konsumsi sendiri serta di jual baik melalui pasar lokal maupun jualan rumahan. Penduduk setempat pada umumnya memang lebih dominan bergantung pada hasil tangkap ikan baik itu dari tambak sendiri ataupun tangkapan dari hasil laut yang bertujuan sebagai penopang kebutuhan ekonomi sehari-hari.

Hasil tangkapan para nelayan di Desa Seuneubok Aceh berupa ikan campuran yaitu seperti ikan tongkol. Ikan merupakan salah satu komoditas makanan yang mengandung berbagai macam zat, selain harga yang umumnya lebih murah, absorpsi protein ikan lebih tinggi dibandingkan dengan produk hewani lain seperti daging sapi dan ayam, karena daging ikan mempunyai serat-serat protein lebih pendek dari pada serat-serat protein daging sapi atau ayam. Menurut (Abdullah et al., n.d.). Ikan merupakan bahan pangan yang sangat baik mutu gizinya, karena mengandung kurang lebih 18 gram protein untuk setiap 100 gram ikan segar. Sedangkan ikan yang telah dikeringkan dapat mencapai kadar protein 40 gram dalam 100 gram ikan kering. Didukung dengan, dibandingkan dengan bahan makanan lainnya, ikan mengandung asam amino essensial yang lengkap dan sangat diperlukan oleh tubuh manusia, oleh karena itu mutu protein ikan sebanding dengan mutu protein daging.

lkan tongkol yaitu ikan yang memiliki kandungan protein sebesar 25\%, jumlah tersebut lebih tinggi dari pada kandungan protein pada ikan tenggiri yang hanya sebesar 21,4\% (Pratiwi et al., 2016). Selain itu, ikan tongkol juga memiliki kandungan asam lemak omega-3 yang cukup tinggi (Diniarti et al., 2020). yaitu sebesar 1,5 g/100g (Pratiwi et al., 2016). Kandungan omega-3 bermanfaat untuk menetralkan kelebihan kolesterol di dalam tubuh manusia. Dapat diketahui juga berdasarkan data statistik kelautan dan perikanan Indonesia, pada tahun 2011-2012 volume produksi pada ikan tongkol mengalami peningkatan sebesar 9,35\%. Sehingga pemanfaatan pengolahan ikan tongkol menjadi produk pangan sangat pontensial untuk dilakukan.

Pengolahan ikan merupakan salah satu cara untuk menyelamatkan hasil panen yang disertai dengan usaha peningkatan nilai tambah melalui rasa, aroma, kenampakan produk serta kandungan gizinya. Adanya usaha diversifikasi produk hasil perikanan diharapkan dapat meningkatkan pendayagunaan dan usaha pengolahan hasil perikanan, khususnya perikanan laut untuk diolah menjadi produk baru yang bergizi tinggi, enak, murah, dan mudah didapat (Pratiwi et al., 2016). Senada dengan penjelasan diatas maka hadirnya Progam Kuliah Kerja Nyata Tematik (KKN-T) yang dilaksanakan oleh Universitas Samudra pada Tahun 2021 guna untuk membantu, mendukung serta mengoptimalkan pendapatan ekonomi masyarakat yang ada di Desa Seuneubok Aceh terkhususnya pada sektor perikanan. salah satu program kerja yang diberikan untuk membantu pemasukan pendapatan masyarakat setempat yaitu olahan daging segar ikan tongkol menjadi produk pangan makanan ikan nugget. Nugget merupakan produk olahan makanan yang digemari oleh masyarakat dikalangan semua usia. 
Nugget merupakan salah satu produk olahan daging dengan menggunakan teknologi restrukturisasi, yaitu teknologi dengan memanfaatkan potongan daging yang relatif kecil dan tidak beraturan, kemudian dilekatkan kembali menjadi ukuran yang lebih besar (Agusta et al., 2020). Nugget yang pada umumnya menggunakan daging ayam, dapat digantikan dengan menggunakan ikan. Pada dasarnya nugget ikan mirip dengan nugget ayam. Pada proses pembuatan nugget dibutuhkan adanya bahan pengisi (filler). Tujuan penambahan bahan-bahan lain, termasuk bahan pengisi adalah meningkatkan daya ikat air, meningkatkan flavor, mengurangi pengerutan selama pemasakan, meningkatkan karakteristik fisik dan kimiawi serta sensoris produk, dan mengurangi biaya formulasi (Novia et al., 2019). Besarnya filler yang ditambahkan pada produk nugget umumnya sebesar 10\% (Pratiwi et al., 2016), hingga 30\% (Minyak et al., 2017). Pembuatan Nugget Ikan lebih mudah dan dapat dijadikan home industry maupun industri besar sehingga mampu meningkatkan produksi dan pendapatan masyarakat nelayan (Wardhani et al., 2021).

Industri pengolahan makanan merupakan usaha yang cukup strategis, karena olahan produk makanan nugget cukup pupuler. Sifatnya yang mudah dalam mengkonsumsi dan komposit kandungan gizinya 15\% meliputi kadar air, abu, protein, lemak, dan kabohidrat (Rusdiana \& Mushollaeni, 2009). program ini dilakukan dengan menggunakan sistem pelatihan edukasi. Edukasi dalam bentuk pelatihan dapat meningkatkan pengetahuan, pemahaman, dan keterampilan seseorang, serta dapat meningkat produktifitas seseorang (Sujadmiko et al., 2021). Memberdayakan masyarakat adalah upaya untuk meningkatkan harkat dan martabat lapisan masyarakat yang dalam kondisi sekarang. Pemberdayaan masyarakat merupakan sebuah konsep pembangunan ekonomi yang merangkum nilai-nilai sosial. Konsep ini mencerminkan paradigma baru pembangunan (Margayaningsih, 2016).

\section{METODE}

Metode yang digunakan dalam program ini adalah penyuluhan dan praktik. Pelaksanaan penyuluhan pembuatan nugget ikan dilaksanakan Kamis, 26 Agustus 2021 pukul 14.00 WIB sampai selesai di salah satu rumah warga Desa Seuneubok Aceh. Kegiatan ini dilakukan dengan metode sosialiasi, tanya jawab, dan praktikum. Penyuluhan berkerjasama dengan pihak perangkat desa, pemuda gampong, serta ibu-ibu rumah tangga yang ada di Desa Seunebok Aceh. sebagai berikut.

Adapun untuk tahapan pelaksanaan kegiatan pengolahan ikan menjadi nugget adalah

a. Tahapan persiapan, yaitu persiapan tim pengabdian yang meliputi penyusunan program kerja, penyusunan modul pelatihan, persiapan sarana dan prasarana pelatihan. Persiapan ini meliputi persiapan kemasan, ikan tongkol berserta bumbu- bumbu yang digunakan, koordinasi lapangan dan sosialisasi.

b. Tahapan Pelaksanaan, terdiri dari beberapa kegiatan yaitu: sosialisasi program, pelatihan pengambilan daging ikan tongkol, memberikan pemahaman inovasi kemasan, da pemasaran dan manajemen usaha.

c. Tahap Evaluasi, terdiri atas tahap monitoring dan evaluasi, Monitoring dilakukan secara intensif oleh tim pelaksana setiap kegiatan berlangsung untuk memastikan agar pelaksanaan kegiatan dapat berjalan sesuai rencana yang telah ditentukan. Evaluasi dilakukan sejalan dengan monitoring, sehingga jika ada kendala akan segera di selesaikan. Evaluasi dilakukan setiap tahap kegiatan, adapun rancangan evaluasi memuat uraian bagaimana dan kapan evaluasi akan dilakukan, Jadi pernyataan yang dapat disampaikan pada tahap evaluasi ini adalah kriteria, indicator pencapaian tujuan, dan tolak ukur yang digunakan untuk menyatakan keberhasilan dari kegiatan yang di lakukan. Memberikan bimbingan kepada masyarakat untuk terus melaksanakan pengolahan ikan tongkol menjadi nugget ikan tongkol dengan berbagai rasa untuk meningkatkan pendapatan dan mendukung program pemerintah dalam pembukaan lapangan kerja baru khususnya di Desa Seuneubok Aceh. 
Tabel 1. Bahan dan Alat

\begin{tabular}{cl}
\hline Jenis peralatan & \multicolumn{1}{c}{ Bahan-bahan } \\
\hline Gilingan/Belender & Tepung Tapioka 100 gram \\
Pisau & Garam 1.000 gram \\
Telenan & Ikan Tongkol 1,5 kg \\
Wajan & Minyak Sayur 3 sdt \\
Meja Stainless & Gula Halus 3 sdt \\
Cetakan/Percetakan & Penyedap Rasa $1 \mathrm{sdt}$ \\
Baskom & Bubuk Lada $1 / 2 \mathrm{sdt}$ \\
Kompor & Bawang Merah 60 gram \\
Panci Kukus & Bawang Putih 30 gram \\
& Jahe 10 gram \\
& Tepung Panko secukupnya \\
& STPP/Sodium tripolifosfat $1 / 4 \mathrm{sdt}$ \\
& Telur secukupnya \\
& Air secukupnya \\
\hline
\end{tabular}

Cara pembuatan nugget ikan adalah sebagai berikut.

a. Potong-potong ikan tongkol, masukkan ke food processor bersama telur, air, bawang putih, garam dan gula. Dan bahan lainya. Proses sampai halus (Blander).

b. Masukkan tepung, proses lagi sampai tercampur rata.

c. Olesi cetakan dengan minyak, lalu masukkan adonan ikan. Ratakan.

d. Kukus selama 30 menit.

e. Potong-potong atau dicetak sesuai selera, celupkan ke telur kocok, lalu gulingkan ke tepung panko. Ulangi proses apabila diperlukan.

f. Goreng dengan minyak banyak dan api sedang sampai cokelat keemasan.

g. Tunggu sedkit mendingin, lalu dimasukan dalam kemasan yang sudah di desain.

h. Siap dipasarkan.

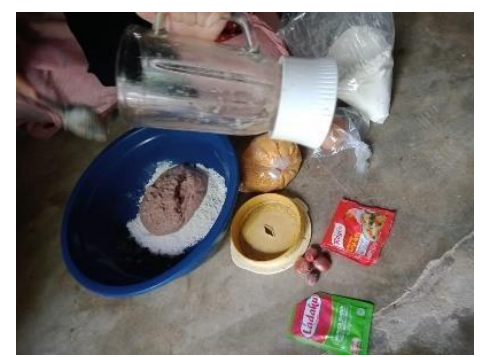

Gambar 1. Campuran Adonan

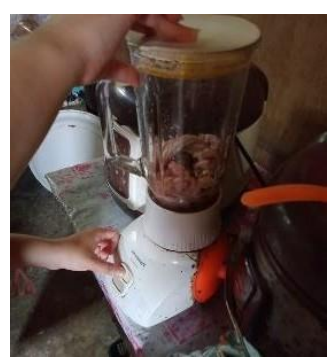

Gambar 2. Ikan di Blander

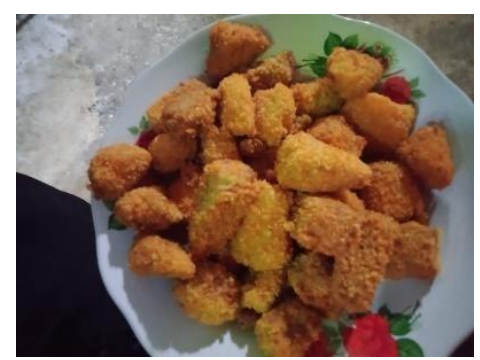

Gambar 3. Hasil Nugget

\section{HASIL DAN PEMBAHASAN}

Pengabdian pada masyarakat adalah usaha untuk menyebar luaskan ilmu pengetahuan, teknologi, dan seni kepada masyarakat. Kegiatan tersebut harus mampu memberikan suatu nilai tambah bagi masyarakat, baik dalam kegiatan ekonomi, kebijakan, dan perubahan perilaku (sosial). Masyarakat Desa Seuneubok Aceh umunya berprofesi sebagai nelayan dan petani. Akan tetapi, lebih cenderung berkerja sebagai nelayan ikan. Hasil tangkapan ikan bermacam jenis, termasuk ikan tongkol. Pemanfaatan daging ikan tongkol menjadi olahan makanan nugget merupakan suatu capaian yang baik dan inovatif serta masyarakat juga lebih berkembang. Masyarakat setempat lebih mendapatkan impect yang baik pada pendapatan ekonomi. setempat.

Hasil dari kegiatan yang dilakukan responsif dari masyarakat terhadap penyuluhan serta pelatihan sangat baik. Masyarakat tertarik dan senang dalam kegiatan yang dilakukan. Program ini menjadi suatu inovasi baru bagi masyarakat Seuneubok Aceh. Masyarakat setempat bisa menambah income melalui penjualan hasil olahan ikan lokal yaitu ikan tongkol menjadi nugget. 
Produk yang telah jadi langsung dikemas pada kemasan yang telah di desain baik dari brand logo sampai ke proses packing. Proses penjualan dikelola baik secara online maupun offline tergantung market pasar yang mengutungkan di daerah tersebut. Produk makanan nugget ini diharapkan memproduksi perharinya mencapai 20-50 pcs.

Manfaat lainya, pada nugget lebih tahan lama tidak cepat busuk seperti ikan. Dan juga lebih hemat waktu pada proses penggorengan. Serta juga dapat menjadi alternatif lain sebagai pengganti ikan untuk di konsumsi baik pada usia anak maupu remaja dan dewasa.

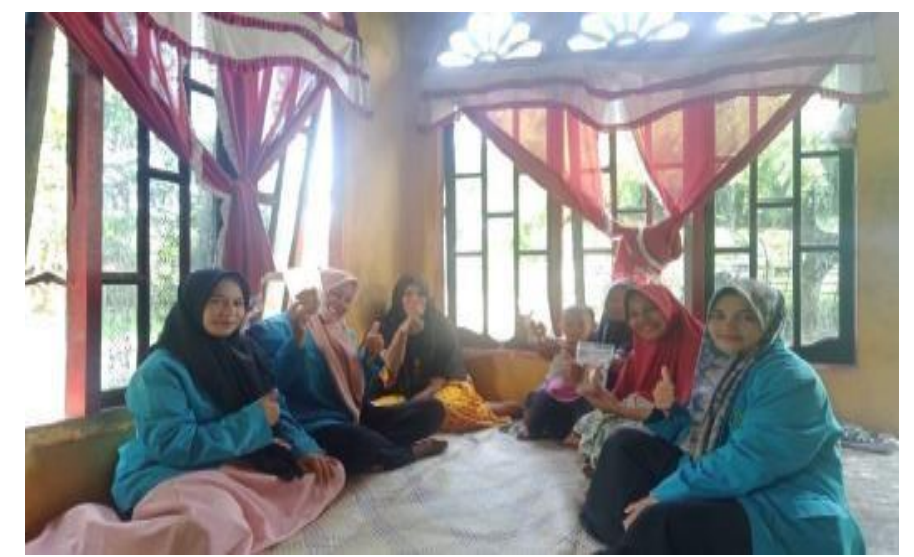

Gambar 4. Penyuluhan hasil jadi produk makanan nugget

\section{KESIMPULAN}

Pengabdian yang dilakukan pada Desa Seuneubok Aceh menghasilkan kegiatan pembuatan makanan berbahan dasar tinggi protein yaitu menghasilkan produk nugget ikan. Menghasilkan suatu produk makanan yang dapat menambah income masyarakat setempat. Kegiatan selanjutnya adalah mengemas produk makanan kedalam kemasan yang telah tersedia kemudian memasarkan produk. langkah akhir memonitoring perkembangan produk dan pengkayaan menu berbahan pangan local yang kaya protein guna meningkat hasil penjualan. Serta memberikan pelanyanan kepada konsumen agar tidak bosan dalam memilih varian rasa.

\section{UCAPAN TERIMA KASIH}

Penulis mengucapkan terima kasih kepada Universitas Samudra yang telah memberikan dukungan secara finansial yang berupa atribut-atribut perlengkapan pengabdian pada masyarakat yang telah terlaksana di bulan Juli tahun 2021. Penulis juga mengucapkan terima kasih kepada dosen pembimbing lapangan yang selalu mendukung, memberikan arahan. penulis juga mengucapkan terima kasih kepada dosen pembimbing pembuatan jurnal yang selalu mendukung, memberikan arahan serta membantu dalam hal finansial. Dan terakhir penulis juga mengucapakan terima kasih kepada masyarakat Desa Seuneubok Aceh yang berkenan menyediakan tempat dan waktu bagi tim pengabdian masyarakat sehingga acara pengabdian masyarakat dapat berjalan baik dan lancar sesuai dengan keinginan atau harapan yang ada

\section{DAFTAR PUSTAKA}

Abdullah, R., Puspitaningsih, A., Halu, U., Manajemen, P. S., Ekonomi, F., Buton, U. M., Author, C., Abdullah, R., Manajemen, P. S., Ekonomi, F., \& Buton, M. (n.d.). PELATIHAN PEMBUATAN NUGGET IKAN, GUNA MENINGKATKAN PENDAPATAN NELAYAN PESISIR. 2666, 298.

Agusta, F. K., Ayu, D. F., \& . R. (2020). Nilai Gizi Dan Karakteristik Organoleptik Nugget Ikan Gabus Dengan Penambahan Kacang Merah. Jurnal Teknologi Pangan, 14(1), 69. https://doi.org/10.33005/jtp.v14i1.2184 
Diniarti, N., Cokrowati, N., Setyowati, D. N., \& Mukhlis, A. (2020). Edukasi Nilai Gizi Ikan Melalui Pelatihan Pembuatan Makanan Olahan Berbahan Baku Ikan Tongkol. Abdi Insani, 7(1), 51. https://doi.org/10.29303/abdiinsani.v7i1.300

Margayaningsih, D. I. (2016). Pemberdayaan Masyarakat Desa Sebagai Upaya Penanggulangan Kemiskinan. Pemberdayaan Masyarakat Desa Sebagai Upaya Penanggulangan Kemisikinan, 9(1).

Minyak, K., Sardin, I., Pemurnian, H., Dari, D. W., Astawan, M., Wulandari, N., Suseno, S. H., Dw, D., Astawan, M., Wulandari, N., \& Sh, S. (2017). Characteristics of Sardin Fish Oil ( Sardinella sp .) Resulted from Stratified Purification. 20(3), 457.

Novia, C., Yahya, Y., \& Soedarmadji, W. (2019). Peningkatan Kemandirian Ekonomi Masyarakat Melalui Aneka Olahan Ikan Tongkol. JMM - Jurnal Masyarakat Merdeka, 2(1), 38. https://doi.org/10.51213/jmm.v2i1.16

Pratiwi, T., Affandi, D. R., \& Manuhara, G. J. (2016). APLIKASI TEPUNG GEMBILI (Dioscorea esculenta) SEBAGAI SUBSTITUSI TEPUNG TERIGU PADA FILLER NUGGET IKAN TONGKOL (Euthynnus affinis). Jurnal Teknologi Hasil Pertanian, 9(1), 35. https://doi.org/10.20961/jthp.v9i2.12852

Rusdiana, E., \& Mushollaeni, W. (2009). Pengolahan Nugget Komposit. Nuana Sains, 9(2), 192.

Sujadmiko, H., Daryono, B. S., Hanini, H., \& Supriyadi, S. (2021). Pengembangan Benih Unggul Semangka Citra Jingga Melalui Teknik Kastrasi dan Polinasi di Desa Depokrejo, Purworejo, Jawa Tengah. Jurnal Pengabdian kepada Masyarakat (Indonesian Journal of Community Engagement), 6(2), 131. https://doi.org/10.22146/jpkm.40610

Wardhani, W., Zulaili, Z., Rahimah, E., \& Simamora, A. M. (2021). Pelatihan Pengolahan Ikan Menjadi Abon di Desa Percut Kabupaten Deli Serdang. COMSEP: Jurnal Pengabdian Kepada Masyarakat, 2(2), 252. 